\title{
Island tourism carrying capacity in the UNESCO Site Laurisilva of Madeira
}

\section{Luís Mota}

Centre for Tourism, Research, Development and Innovation-CiTUR, University of Madeira, Funchal, Portugal

Isoaresmota@gmail.com (corresponding author)

\section{Mara Franco}

Centre for Tourism, Research, Development and Innovation-CiTUR, University of Madeira, Funchal, Portugal

mara.franco@staff.uma.pt

\section{Rossana Santos}

Centre for Tourism, Research, Development and Innovation-CiTUR, University of Madeira, Funchal, Portugal

rossana.santos@staff.uma.pt

\begin{abstract}
The Laurisilva of Madeira is an important natural resource as well as a location for nature-based tourism and recreational activities. Despite UNESCO's concerns and recommendations for assessing tourism capacity, the local population is perceived as overusing this resource; yet precisely how many tourists visit its most popular areas remains unknown. Tourism carrying capacity (TCC) was assessed on two Rabaçal trails using a specific formulation relating physical aspects to environmental correction factors. Tourism carrying capacity was found to be below theoretical limits, and trail access was not restricted despite being a major concern in natural resource management.
\end{abstract}

Keywords: Carrying capacity, islands, Laurisilva, Madeira, sustainable management, tourism, UNESCO

https://doi.org/10.24043/isj.143 • Received March 2020, Early access August 2020

(C) 2020 - Institute of Island Studies, University of Prince Edward Island, Canada.

\section{Introduction}

The measurement of tourism carrying capacity (TCC) has particular relevance in the European Union as a tool to manage the expected sharp rise in tourism in the coming decade, which is forecast to increase on average by 9 million international tourist arrivals annually (UNTWO, 2018). However, in 2020 the COVID-19 outbreak challenged every projection 
due to restrictions on the movement of people across borders and according to the degrees of infection, requiring a new forecast for the tourism rise at global scale.

European regions have already set long-term goals using smart specialisation strategies to build competitive advantages in high-value-added activities (Balland et al., 2018). Portugal has seventeen World Heritage Sites as designated by the United Nations Educational, Scientific and Cultural Organisation (UNESCO); the Laurisilva of Madeira is classified as 'natural heritage' and the remaining sites as 'cultural heritage'. Many sites are participating in UNESCO's Man and the Biosphere Programme and some researchers have already begun developing tools to measure and manage tourism carrying capacity due to crowding in marine environments (Bentz et al., 2015) and on hiking trails (Queiroz et al., 2014) in the Azores. Other important ecosystems, such as beaches in Cascais and Algarve (Ribeiro et al., 2011; Zacarias et al., 2011), have also been assessed for TCC. Consequently, Madeira Island requires a permanent tool for monitoring and managing visitors to boost the area's sustainability, not only environmentally but also through urban-quality, landscape, and social measures (ARDITI, 2015).

Island tourism and services have been explored extensively in recent research. One of the main reasons is tourism's importance for economic development; it is the main driver of the economy. Tourism's growth is limited by natural, environmental, and social constraints. Therefore, it is necessary to agree on sustainability levels for each destination, which can be resource-based (McKercher, 1993), activity-based (Butler, 2011), or community-based (Hughes, 1995). Consequently, the objective of this study was to examine the actual visitation level compared to physical thresholds at the UNESCO Site Laurisilva of Madeira, drawing the research question to understand visitation versus carrying capacity.

The whole island of Madeira depends on the laurel forest (laurisilva) for freshwater supply and tourism activity; therefore, calculation of TCC has been requested by the local population and by UNESCO to prevent overcrowding and preserve natural resources. Recent reports on the Laurisilva's state of conservation on Madeira Island warned about various threats, namely the invasion of non-native species introduced by human activity (Hennessy \& McCleary, 2011; IUCN, 2017), increased water usage, and tourist saturation, all of which could jeopardise the site's sustainability. Measuring the carrying capacity of seemingly overexploited touristic areas, such as Rabaçal (IUCN, 2017), has been strongly advised, and UNESCO (2009, p. 73) has highlighted the lack of "control of carrying capacity and support infrastructure and services (information, car parking, safety instructions)."

\section{Tourism carrying capacity}

Tourism managers, concerned with possible impacts from visitor flow, use operational data in the planning and management of attractions (González-Guerrero et al., 2016). The importance of carrying capacity has been growing since the 1960s, however, is a complex calculation and difficult to address in tourism. Carrying capacity is a management concept dependent on measurable criteria, which is often difficult to obtain, and has always been linked to natural resources and environmental management; thus, it is constrained by ecological factors (Manning, 2011). The concept of carrying capacity was first introduced in the mid-1930s, as growing demand for outdoor recreation prompted concerns from US National Park managers (Manning, 2011). The use of natural resources for public use requires 
visitor management strategies; however, it is difficult to balance the real impacts from usage that provides a high-standard visitor experience, as misuse can cause degradation of the resource (Manning, 2007, 2011).

Determining carrying capacity is linked to circumstances other than natural assets (Wagar, 1964), which are acknowledged as a "multi-dimensional compromise" (Bertocchi et al, 2020, p. 3). TCC includes a diversity of "physical, social, and economic effects induced by tourism, each of which is characterised by its characteristics and consequences" (Bertocchi et al., 2020, p. 3). There are associated thresholds, linked mainly to physical limits within a certain area, that do not reflect social values and perceptions. Such limits will never be comprehensive enough to manage tourism because social values such as human values, perception, satisfaction levels, and needs must be considered (Wagar, 1964).

TCC can be considered from different perspectives; Stankey and colleagues (1985) established a framework for Limits of Acceptable Change (LAC), focused on desired conditions in recreational areas instead of tolerance limits; Visitor Impact Management (VIM) was developed by researchers and a Conservation Association addressing impact-linked questions to determine problem conditions, potential causal factors, and potential management strategies (Kuss et al., 1990). The Visitor Experience Resource Protection (VERP) was developed by the U.S. National Park Service (1997), comprising a set of indicators and standards of excellence designed to appraise projected conditions of park resources and visitor practices.

The concept of carrying capacity has changed from limit-setting to understanding levels of acceptance and desired condition (Joshi \& Dahal, 2019; Manning, 2002, 2011). Hence, the social carrying capacity is directly related to different levels of perception by locals and visitors (Zacarias et al., 2011), bearing complexities for understanding levels of acceptance regarding the quality of visitor experience (Manning, 2001) and satisfaction for a destination (Joshi \& Dahal, 2019). The challenge is to provide knowledge that can assist the creation of management frameworks and offer guidance to decisionmakers. Registering social data regarding visitor experience leads to an understanding of visitor use with subsequent improvements at the management level. Thus, appropriate indicators can be developed for monitoring identified issues. Management frameworks such as LAC, VERP, and VIM "are designed to respond to change, many have only been applied on fairly small scales, such as a particular trail or feature" (Miller et al., 2017, p. 41). For instance, Figueroa and Rotarou (2016) studied the role of Easter Island residents in tourism development and highlighted that tourism can be considered a push-pull factor and is expected to be a determinant economic activity for island development. Reducing the number of parking spaces to curtail access to a certain trail causes impacts such as traffic congestion or - when visitors are forced to park further away - the creation of alternative paths connecting visitors to the main trail (Miller et al., 2017).

Studying carrying capacity involves physical, infrastructural, environmental, economic, social, and perceptual subjects that can be discussed regarding their calculation and how they can be used for site management. Nevertheless, carrying capacity is a starting point for management when considering a variety of interactions between the actual conditions of the resource used for recreational use and the perceived quality, quantity, and quality of the experience from the supply and demand side. Other narratives have reported visitor satisfaction levels influencing the overall judgment of natural areas (Stankey, 1988). Inskeep 
(1991) added to the list of TCC socio-cultural effects on host values, primarily concentrating on ecological terms and deterioration of visited areas (Manning, 2002).

The experience is now related to social characteristics, increasing conservation concerns regarding site-visitation impacts. An example is Prakash and colleagues' (2019) study relating the social factor reporting visitor dissatisfaction with park management, safety issues, and onsite ethical behaviour; however, this cannot be used as a standalone variable for measuring tourism capacity (Jurado et al., 2013) as human values influence the calculation of TCC. It is difficult to find the actual visitation threshold (Saarinen, 2006). For example, residents who are more familiar with a tourist attraction register a different sense of crowding to outsiders; patterns for locals' and foreign visitors' satisfaction levels vary greatly in line with behavioural attitudes (Zacarias et al., 2011). Additionally, defining visitor use based on satisfaction levels represents a lack of specificity, as it does not always consider differences among visitors. Hence, the social pillar affecting sustainability shall consider the residents' opinion regarding tourism development, the attraction's carrying capacity, and, on a larger scale, the island carrying capacity (Figueroa \& Rotarou, 2016).

Whilst Bertocchi et al. (2020) refer to social TCC as an additional effect caused by tourism activity on residents, others consider it "the maximum level of use that can be absorbed by an area without an unacceptable decline in the quality of experience of visitors and without unacceptable adverse impact on the area's society" (López-Bonilla \& López-Bonilla, 2008, p. 118). For the definition of social TCC, the quality of the overall visitor experience was assessed before visiting other destinations, and the level of tolerance registered by locals in regard to having tourists visit was also considered. Finding a limit is challenging, as this component relies on value judgement regarding subjective characteristics from a tourist attraction or site. In López-Bonilla and López-Bonilla's (2008), social TCC was measured through a ratio based on satisfaction levels of both satisfied and unsatisfied tourists in different seasons. Psychological factors suggested changes in visitor satisfaction level, and a significant decrease can be understood as a signal to review visitor tolerance levels for a destination. Hence, it is not the maximum number of visitors that should be of concern, but rather the drop in measured satisfaction. According to Shelby and Heberlein (1986, qtd. in Jurado et al., 2013, p. 10):

if more than two-thirds of the visitors say that they are crowded, it appears likely that the capacity has been exceeded. If less than one third senses the overcrowding, the area is probably below the load capacity. When the perception of the mass is between these thresholds, no determination can be made with this rule.

There is also the gathering of people, which must be understood as a normative factor providing judgement about a case. In a natural conservation setting, a small number of people can be considered crowded, whereas the presence of many others might be considered acceptable in a theatre or beach setting. Different users have different perceptions of crowding; as Zehrer and Raich (2016) argue, individual performance in an outdoor environment and during outdoor activities is linked to the perception of crowding because it depends on independent variables and a variety of situations. In their study on perceived crowding at a ski resort in Austria, age and gender were considered "influencing factors" (Zehrer \& Raich, 2016, p. 90). The perception of congested slopes was highlighted by younger and older respondents $(34.0 \%$ and $49.3 \%)$ at the line of 38 years old. While some studies have found 
that younger generations were more sensitive to crowding (Jurado et al., 2013), Zehrer and Raich's (2016) study addresses the type of outdoor experience (rather than visitor age) as influencing visitor experience and found that $60.8 \%$ of women were comfortable with the number of people skiing on the slopes. Mirkarimi, Mohammadzadeh, and Galdavi (2015) assessed the social carrying capacity of Daland Forest Park in Iran finding that around $60 \%$ of visitors were not inconvenienced by moderately crowded areas, and that women were found to be more sensitive to crowding levels. In their analysis of social carrying capacity for tourist destinations on the Costa del Sol in Spain, Jurado et al. (2013) found that tourist gender influences the perception of the number of people gathering at a site, and that people less responsive to crowding were older than 40 , mostly educated to university level, and had a monthly income over $€ 3151$ (Jurado et al., 2013). Hence, while perceived crowding is related to service quality (Saveriades, 2000), increasing the number of visitors does not necessarily affect satisfaction levels in outdoor settings (Shelby \& Heberlein, 1987); "satisfaction may influence the overall satisfaction of the tourist experience but may not be the only variable with which to measure the carrying capacity" (Jurado et al., 2013, p. 4).

Using a holistic approach, TCC provides "benefits in terms of raising awareness on sustainable tourism in national parks" (Guo \& Chung, 2017, p. 197) and is useful for the planning and management of sustainable tourism (Mexa \& Coccossis, in Bertocchi et al., 2020; Shelby \& Heberlein, 1984). In recent decades, there is a disregard for the subject when it is in fact significant, and research implications affirm the suggestion for critical exploration linked to overtourism. To reduce impacts on tourism destinations, many residents are now requesting tourist limits (Butler, 2019). Through TCC, tourism pressure can be better analysed for resident tolerance levels and the quality of experience.

Papageorgiou and Brotherton (in Bertocchi et al., 2020) recommend further study of how human activities are dependent on the environment, and vice-versa. Each destination or attraction has a carrying capacity (Saveriades, 2000). Carrying capacity is a relation of specific magnitudes and relies on a variety of methodologies, and yet there is no universal way to assess it. When calculating physical numbers of tourists, one must consider different carrying capacities related to different limits of sustainability. Linear programming models are useful for exploring satisfaction levels of choices among decision-makers (Kuchta, 2005). Canestrelli and Costa (1991) built a model for optimal level distribution of tourists in Venice by considering the benefits and costs from tourism, which was recently updated by Bertocchi and colleagues (2020).

Another way to calculate TCC is by using Cifuentes' (1992) methodology, relying on physical numbers to establish visitor limits for a natural attraction. López-Bonilla and LópezBonilla (2008) used indicators to measure satisfaction levels with tourism services and other synthetic indicators capable of evaluating the expansion of tourist destinations. This methodology can be adapted to any coastal area based on two scenarios: weak and strong sustainability (Jurado et al., 2012).

\section{Madeira's UNESCO site for tourism use}

The tourism industry is the main driver of the Madeira Island economy, representing 26.6\% of the regional GDP in 2015 (DREM, 2018). Two-thirds of the island is a natural park covered with levadas (human-made water channels with pathways alongside), which are used 
by both residents and visitors (Oliveira \& Pereira, 2008). Tourism on Madeira relies on the availability of natural resources for visitor consumption, in particular the laurel forest UNESCO World Heritage Site, Laurisilva of Madeira (UNESCO, 1999). The forest attracts special interest as it is a water source, which led to the construction of the highland waterways: approximately $1400 \mathrm{~km}$ of human-made infrastructure which constantly channels water from the north of the island for agricultural use, including sugarcane plantations and vineyards producing Madeira wine (Quintal \& Fernandes, 2010). The paths alongside the highland waterways, or levadas, which connect villages and urban structures, are often used for tourist activities as they enable visitors to walk through the laurel forest, offering them a globally unique sightseeing experience.

The Laurisilva of Madeira protects the primary laurel forest, which is present in Madeira, the Azores, and the Canary Islands. Its ecological value lies in its biological diversity, as it exists in an ecosystem that plays an important role in offsetting the island's hydrologic system:

The site contains the largest surviving relict of the virtually extinct laurisilva forest type that was once widespread in Europe. This forest type is considered a centre of plant diversity containing numerous rare, relict and endemic species, especially of bryophytes, ferns and flowering plants. It also has a very rich invertebrate fauna. Endemic species include the Madeiran long-toed pigeon and some 66 species of vascular plants. (UNESCO, 1999, p. 1)

The UNESCO inscription of the Laurisilva of Madeira (1999) responds to four natural criteria:

(i) Earth's history and geological features

(ii) Ecological processes

(iii) Superlative natural phenomena, scenic beauty

(iv) Biodiversity and threatened species.

In 1999, when UNESCO designated the Laurisilva of Madeira a World Heritage Site, it raised conservation concerns regarding impacts from tourism, including visitor attendance and stated that carrying capacity should be controlled and car-parking infrastructure and safety measures put in place. An analysis conducted by the International Union for Conservation of Nature (IUCN) in 2014 classified impacts on the site from tourism/visitors/ recreation as minor, but on the increase. Since 2017, the IUCN has expressed significant concerns regarding its last assessment, in which it designated the Laurisilva of Madeira 'orange' - a downgrade from the previous report in which the laurel forest was designated 'light green' and described as good with some concerns (IUCN, 2017). The Institute of Forests and Nature Conservation (IFCN in Portuguese), the property stakeholder, protested the 'orange' rating, maintaining that the IUCN did not follow standard procedure by failing to assess the state of the forest and issuing an unfair report. In March 2019, the Regional Secretary of the Environment and Natural Resources, Susana Prada, was called to the Regional Parliament to clarify the downgrade (Sousa, 2019). The 2017 report stated that high tourist numbers call for suitable management measures to avert threats to site conservation, naming Rabaçal and Ribeiro Frio as particular areas where tourism/visitors/recreational usage is beyond capacity limits. Also identified were issues relating to solid-waste management and irresponsible site usage for 
human physiological needs. The report indicated that site overcapacity highlights the need to study visitor impacts in terms of noise and bird feeding, and that the mass influx of tourists, coupled with personnel and funding shortages, hinders adequate management of the site.

After consulting the IFCN for existing data and information related to tourism activities in the Laurisilva of Madeira, it was determined that data were scarce and there were no studies on tourism carrying capacity; a research gap which this study seeks to address. Moreover, the property managers can benefit from a validated methodology for carrying capacities, which can be applied to any land-based property.

\section{Methodology}

Cifuentes (1992) proposed a specific methodology for the calculation of the maximum number of visitors to a natural attraction, and the output is based on real conditions (physical, environmental, and management) of a study area giving the respective TCC for this study.

This procedure was used in a variety of international studies, such as in Spain, where García and Ventura (2014) studied touristic and public use of natural protected areas to assess visitor impacts using carrying capacity. García Ventura (2010) also studied the carrying capacity of walking trails in both the Hoces del Rio Riaza Natural Park and Cabañeros National Park. In Portugal, Zacarias et al. (2011) assessed tourist capacity to determine thresholds for beach management, introducing a socio-cultural component of TCC as a significant measure by asking 275 beach users about topics related to satisfaction levels and a sense of crowding at the beach. Queiroz et al. (2014) determined the tourism carrying capacity in the Azorean Islands using Cifuentes' (1992) correction factors for social, precipitation, light, and accessibility, and reported that the social factor had a significant impact on results when considering groups of 15 people and a minimum group distance of $250 \mathrm{~m}$. Moreover, tourism capacity shall be taken as a borderline relating to actions to minimise tourism impacts.

Physical thresholds related to TCC for site management on Madeira Island were calculated by collecting statistical data from field observations of visitor flow in the Rabaçal area between May 15th and June 17th, 2018, from 11:00 am to 5:00 pm each day. A fourdigit Velleman manual counter was used to register how many people used the trails.

\section{Technical description of the sites in Rabaçal}

Rabaçal is a nature reserve composed of green areas surrounding access from the ranger house to Casa do Rabaçal, an old shelter converted into a café, and a two-bedroom lodging for visitors in the middle of the laurel forest. There are five walking trails with different levels of difficulty and typology. The most visited are the Levada das 25 Fontes (PR6) and Levada do Risco (PR6.1); the Levada do Alecrim and Vereda da Lagoa do Vento are the least known to visitors. Accordingly, the current study focused only on the PR6 and PR6.1. For TCC physical figures, the starting points of PR6 and PR6.1 were taken to be at Casa do Rabaçal, resulting in registration of 2,900 visitors walking in both trail directions.

Park rangers and maintenance staff were often seen on the trails overseeing visitors and conducting maintenance work to the trail or the stone bed of the waterways, to increase the efficient and safe access to the levadas. The trails are linear and share the start/end points. Trails were clearly identified with arrows indicating directions and length. There are alternative paths connecting PR6 and PR6.1, but these are not clearly identified and maintained. The 
trails are not always flat and in many locations are only wide enough for one person, and go up and down the hills, making safety an issue at all times. There are steep parts of the trails where it is difficult to walk due to slippery ground, and on rainy days they become more difficult to hike and less safe due to mud zones; thus there is a high risk of accidents.

Some parts of the trails are suitable for gatherings of people; it is common to see groups of up to 35 people. Such areas become hotspots for resting, eating, or just enjoying the laurel forest, and some were even used for discarding rubbish. Overall, trails were well maintained and clean, but debris was noted such as paper tissues, plastic film, sweet wrappers, plastic bottles, and broken glass bottles, all linked to food and drink consumption while hiking. Although Rabaçal has toilet facilities at the café, people were seen to relieve themselves by the side of the trail, contributing to the common sight of faecal matter with paper tissue at the side of the trails, in particular along PR6.

The Levada das 25 Fontes trail (PR6) is in the Calheta Municipality. Starting at Casa do Rabaçal, the Levada das 25 Fontes is $2.7 \mathrm{~km}$ long and ends at the 25 Fontes lagoon. As the trail is one-way, users must make the return journey back along the on-average $1.5 \mathrm{~m}$-wide route, which takes approximately 3 hours roundtrip. In the second half of 2018, the IFCN restored old paths to make a circular route returning from the lagoon, where PR6 is narrower, however users still need to give way to those walking in the opposite direction due to its narrowness. Moreover, they can be forced to walk near the edge, where vertigo sufferers are at risk if they look down the steep mountain drop.

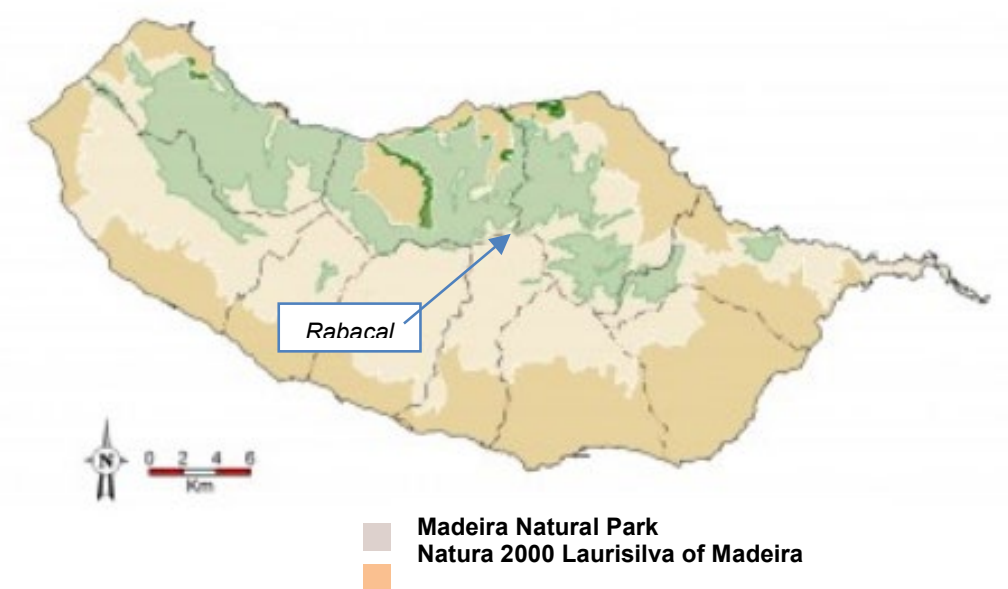

Figure 1: Map of Madeira Island with the laurel forest and the Natural Park of Madeira. Source: http://ifcn.madeira.gov.pt

The Risco trail (PR6.1) is also in the Calheta Municipality. This $1.16 \mathrm{~km}$ stone trail starts on a gentle incline at Casa do Rabaçal and becomes flat after $200 \mathrm{~m}$. The trail has an average width of $2.5 \mathrm{~m}$ and takes around 2 hours to complete. The last section ends in front of an impressive $100 \mathrm{~m}$ waterfall.

\section{Results and discussion}

In Rabaçal, the Physical Carrying Capacity (PCC) and the Real Carrying Capacity (RCC) were measured of both trails, PR6 and PR6.1, using Cifuentes' methodology (1992; 
Cifuentes et al., 1999). There was also an attempt to measure the respective Effective Carrying Capacity (ECC), with $\mathrm{PCC} \geq \mathrm{RCC} \geq \mathrm{ECC}$. To provide a comprehensive picture of the managing capacity of the UNESCO site, it was originally planned to calculate the ECC, but at the time of this work, data were not available for the calculation.

The PCC is the relationship between the physical space available for use, associated with a rotation factor $(N V)$ giving the number of times that one person can visit the trail in one day: $\mathrm{PCC}=[(\mathrm{V} / \mathrm{A}) \star(\mathrm{L} \star \mathrm{W}) \star \mathrm{NV}]$ The total length $(L)$ of the PR6/PR6.1 trail was considered, as well as the average width $(W)$ and, as suggested by Cifuentes (1992), in the case of trails the area $(A)$ used per person $(V)$ was considered to be $1 \mathrm{~m}^{2}$. Rabaçal is open all year round without any time restrictions for visiting; thus, opening times were considered as 2488.7 hours of sun per year registered on Madeira Island (IPMA, 2018), divided by the number of days of the year ( $\mathrm{H} v, \mathrm{~h} /$ day). This figure was then divided by the recommended time to visit PR6/PR6.1 (Tv, h/visit/visitor), providing the daily rotation factor $N V$.

The RCC considered variables of a different nature, namely PCC multiplied by correction factors, $c f_{n}=1-\left(L_{x} / T_{x}\right)$, expressing the relation of the maximum value of a variable when related to the total magnitude of the same variable on the trail. Hence, RCC = PCC $\left(\mathrm{cf}_{\mathrm{rf}} \star \mathrm{cf}_{\mathrm{sw}} \star \mathrm{cf}_{\mathrm{ss}} \star \mathrm{cf}_{\mathrm{tc}} \star \mathrm{cf}_{\text {erod }} \star \mathrm{cf}_{\mathrm{Acc}} \star \mathrm{cf}_{\mathrm{fl}}\right)$ with all factors available for measurement on the site. Rainfall $\left(c f_{f f}\right)$ is a determinant factor for visitors unwilling to be exposed to heavy rain at high altitude (Apollo, 2017; Pröbstl-Haider et al., 2016). Accordingly, from the 17 weather stations on Madeira Island, Bica da Cana was the most relevant at the comparable altitude (IPMA, 2018), registering a higher volume of rain from September to May and a limiting magnitude $\left(M l_{p p}\right)$ of 99 days of rain with more than $1 \mathrm{~mm}$ near Rabaçal in 2017. Strong wind $\left(c f_{s w}\right)$ can greatly influence safety, satisfaction level, and decision to go hiking at high mountain levels (Pröbstl-Haider et al., 2016). For wind measurement, Chão do Areeiro was the weather station most relevant for the study; it registered winds blowing from the northeast. Furthermore, it was assumed that strong winds blowing with an average speed of more than $35 \mathrm{~km} / \mathrm{h}$ have a higher impact. The limiting magnitude $\left(M l_{s w}\right)$ was given by 253 days, with strong wind in the total magnitude $\left(M t_{s w}\right)$ of 365 days of the year (IPMA, 2018).

The vegetation of the laurel forest attenuates the sunshine factor ( $f s s)$ on Rabaçal, although parts of the trails are uncovered, exposing users to the sun. During summer when temperatures are higher, clouds, relative humidity, sunshine and the sun's ultraviolet radiation play an important role in visiting Rabaçal. The Portuguese Association of Cutaneous Cancer (APCC) and the General Directorate of Health Care in Portugal (DGS) advise people to avoid sun exposure from 12:00 pm - 4:00 pm during summer (APCC, 2018; DGS, 2018). Hence, for the trail length, the portions lacking coverage $(m n c, \mathrm{~m})$ give the limiting magnitude for sunshine (hlss, hr/year) given by the sum of days with low rain within the period JuneSeptember multiplied by four hours and September-May, referring to the higher precipitation (>50 mm), multiplied by 2 hours. The total magnitude of the variable is given by the number of hours that Rabaçal is open to the public ( $H v, \mathrm{~h} /$ day). Temporary closing $(c f t c)$ is composed of the number of days that the trails were closed by the Regional Service for Civil Protection (Mltc) (SRPC-IP-RAM, 2018) divided by the number of days of the year that the trail is open to the public $(M t t c)$.

The first $200 \mathrm{~m}$ of PR6.1 are on a medium-grade slope at 10-20\%, with the rest nearly flat at a height of $1000 \mathrm{~m}$. PR6 shares the first $300 \mathrm{~m}$, then heads down to a height of $941 \mathrm{~m}$ 
along a steep slope of more than 20\%. As per Cifuentes et al. (1999), only portions of the trail with a medium and high grade of erodibility are considered to be more susceptible to highergrade erosion and, therefore, the current authors assign grade factors 1 and 1.5 accordingly. Hence, the correction factor for Erodibility (cferod) calculated has Mlerod as the sum of the portions with medium and high grade (Mlerodm; Mlerodh) multiplied by the respective grade factor: the accessibility factor $(c f A c c)$ measured the portions of the trail for people moving freely without difficulty due to steep ground. For this reason, Cifuentes et al. (1999) took the same grade factors as for erodibility. Hence, the correction factor was calculated with Mlacc being the sum of the portions with medium and high grade (Mlaccm; Mlacch) multiplied by the respective grade factor. Flooding (cffl) was measured at $20 \%$, indicating the portion of the trail swamped during rainfall. This calculation gives the relation between the length of the trail flooded and the total trail length.

Table 1: Tourism capacity for PR6/PR6.1, with PCC > RCC (visit/day).

\begin{tabular}{|l|l|l|l|l|l|l|}
\hline Trail & $\begin{array}{l}\text { Length } \\
(\mathrm{m})\end{array}$ & $\begin{array}{l}\text { Rotation factor } \\
\text { NV } \\
\text { (visit/day/visitor) }\end{array}$ & $\begin{array}{l}\text { PCC } \\
\text { (visit/day) }\end{array}$ & $\begin{array}{l}\text { RCC } \\
\text { (visit/day) }\end{array}$ & $\begin{array}{l}\text { Field } \\
\text { observation for } \\
\text { max 2-way } \\
\text { visitors }\end{array}$ & $\begin{array}{l}\text { Field } \\
\text { observation } \\
\text { for average 2- } \\
\text { way visitors }\end{array}$ \\
\hline $\begin{array}{l}\text { PR6 - 25 } \\
\text { Fontes }\end{array}$ & 2800 & 2 & 9546 & 1420 & 614 \\
\hline $\begin{array}{l}\text { PR 6.1 - } \\
\text { Risco }\end{array}$ & 1200 & 3 & 10228 & 1220 & 64 & \\
\hline
\end{tabular}

The results shown in Table 1 answer the proposed objective, which was set to understand visitation metrics compared to physical thresholds at the UNESCO site Laurisilva of Madeira. PR6 has more than double the length of PR6.1 but is narrower on average. Considering that the rotation factor allows 2 to 3 visits a day per visitor, TCC values are comparable for both trails. PCC gives a greater number then RCC, and the fact is given by the correction factors used for calculation, decreasing PCC 6.72 times in the case of PR6 (1420 visit/day), and 8.38 times in the case of PR6.1 (1220 visit/day). When compared to the maximum number of visits on the sampling dates, TCC remains far within its limits. Because trails are not in a circular route, the average number of users hiking in both directions indicated that for the period May-June, PR6/PR6.1 was at about one-third of the RCC. Therefore, direct observations placed visitation to PR6 and PR6.1 below the physical limits calculated for Rabaçal, the UNESCO Site Laurisilva of Madeira.

This study introduces the first assessment of TCC in the Laurisilva of Madeira, with physical values being subjective (Saarinen, 2006) and certain assumptions made to compute correction factors referring to January-December 2017. Calculations can be more accurate if related to a more representative weather station installed in a nearby area from PR6/PR6.1, increasing accuracy for monthly calculations throughout the year (Zacarias et al., 2011). For example, strong winds (Pröbstl-Haider et al., 2016) and rainfall levels (IPMA, 2018) will be more accurately recorded when measurements are taken near the trails.

\section{Conclusion}


Carrying capacity values can be used in a pre-emptive strategy to protect an area by limiting visitor access (Zacarias et al., 2011). Such assessments identify strengths and weaknesses attached to visitor management (López-Bonilla \& López-Bonilla, 2008). Today, understanding levels of acceptance and preferred condition (Joshi \& Dahal, 2019; Manning, 2002, 2011) have great importance for controlling carrying capacity.

This paper reports the calculation of metrics for carrying capacity related to Rabaçal, an important tourism asset found on Madeira Island. The current assessment of TCC following the proposed methodology offers a starting point for managing tourism, as it can determine visitation boundaries related to sustainability. Its advantages (Cifuentes, 1992; Cifuentes et al., 1999) have been emphasised by Gonzalez-Guerrero and colleagues (2016) by expressing the ease of calculating carrying capacity in an outdoor environment, not involving many people, and requiring specific information available to feed the variables. The current analysis of TCC confers to Madeira Island a robust base for assessment of sustainable tourism development; however, it is just a performance indicator and forecast of carrying capacity (Ye et al., 2020). Findings indicate that the visitation limits are still below those thought by local players for the Laurisilva of Madeira; therefore, the site is still used in a sustainable way. Control of carrying capacity (IUCN, 2014, 2017; UNESCO, 2009, 2014) now has a reliable methodology for assessing visitation to Rabaçal and is a tool for improving site management.

\section{Limitations and implications}

Data from the weather stations regarding rainfall and wind speed were not always available from the nearest point. A possible solution would be to use a portable weather station to take measurements directly at PR6/PR6.1 and triangulate data with nearby stations.

On Madeira Island, there is little difference between high and low tourism season, although there is a peak in August and there are few tourists in October-November. According to the Regional Tourism Board, local celebrations such as the flower festival and the Atlantic festival attract many tourists and form part of a strategy to break seasonality. In May-June, when this study was conducted, there are no cruise line arrivals at Madeira Island. The current study was an attempt to verify if visitation to Rabaçal was affected by tourism arrivals and, while Madeira is not considered a seasonal tourist destination, across the year it registers different percentages of tourist country of origin (DREM, 2018) and, as a result, satisfaction values might differ throughout the year.

\section{Disclosure statement}

No potential conflict of interest is reported by the authors.

\section{References}

APCC (2018). Associação Portuguesa de Cancro Cutâneo: Cuidados a ter na exposição solar. http://www.apcancrocutaneo.pt/index.php/prevencao/cuidados-a-ter

Apollo, M. (2017). The true accessibility of mountaineering: The case of the High Himalaya. Journal of Outdoor Recreation and Tourism, 17, 29-43. https://doi.org/10.1016/j.jort.2016.12.001 
ARDITI (2015). Madeira 2020: Estratégia Regional de Especialização Inteligente. https://ris3.arditi.pt/?page $\mathrm{id}=5$

Balland, P.A., Boschma, R., Crespo, J., \& Rigby, D.L. (2018). Smart specialization policy in the European Union: relatedness, knowledge complexity and regional diversification. Regional Studies, 53, 1-17. https://doi.org/10.1080/00343404.2018.1437900

Bentz, J., Rodrigues, A., Dearden, P., Calado, H., \& Lopes, F. (2015). Crowding in marine environments: Divers and whale watchers in the Azores. Ocean E Coastal Management, 109, 77-85. https://doi.org/10.1016/j.ocecoaman.2015.03.001

Bertocchi, D., Camatti, N., Giove, S., \& Borg, J. (2020). Venice and overtourism: Simulating sustainable development scenarios through a tourism carrying capacity model. Sustainability, 12, 512. https://doi.org/10.3390/su12020512

Butler, R. (2019). Tourism carrying capacity research: a perspective article. Tourism Review, 75(1), 207-211. https://doi.org/10.1108/tr-05-2019-0194

Butler, R. (2011). Tourism area life cycle. Goodfellow.

Canestrelli, E., \& Costa, P. (1991). Tourist carrying capacity: A fuzzy approach. Annals of Tourism Research, 18, 295-311. https://doi.org/10.1016/0160-7383(91)90010-9

Cifuentes, M. (1992). Determinación de capacidad de carga turística enáreas protegidas. CATIE, Programa de Manejo Integrado de Recursos Naturales.

Cifuentes, M., Mesquita, C.A.B., Méndez, J., Morales, M.E., Aguilar, N., Cancino, D., Gallo, M., Jolón, M., Ramirez, C., Ribeiro, N., Sandoval, E., \& Turcios, M. (1999). Capacidad de carga turística de las áreas de uso público del Monumento Nacional Guayabo, Costa Rica (9968825034). WWF Centroamérica. http://awsassets.panda.org/downloads/wwfca guayabo.pdf

DGS (2018). Direção Geral de Saúde: Cuidados a ter com a exposição solar. https://www.dgs.pt/saude-ambiental-calor/exposicao-solar.aspx

DREM (2018). Conta satélite do turismo da Região Autónoma da Madeira 2015. http://www.visitmadeira.pt/Admin/Public/Download.aspx?file=Files\%2FFiles\%2FVi sitMadeira\%2FEstudos\%2Fm-DREM-CST-Conta-Satelite-do-Turismo-2015.pdf

Figueroa, E., \& Rotarou, E. (2016). Tourism as the development driver of Easter Island: The key role of resident perceptions. Island Studies Journal, 11(1), 245-264.

García Ventura, D. (2010). Análisis de la capacidad de acogida del sistema de uso público del Parque Nacional de Cabañeros. https://docplayer.es/15373335-Analisis-de-la-capacidad-deacogida-del-sistema-de-uso-publico-del-parque-nacional-de-cabaneros.html

García, J.G.L., \& Ventura, D.G. (2014). Capacidad de acogida de uso público en los espacios naturales protegids. In O. A. P. N. (Ed.), Cuadernos de la Red de Parques Nacionales (Vol. 3). La Trébere.

Gonzalez-Guerrero, G., Robles, A.K.O., Perez, M.E.V., Ibarra, R.M., \& Martinez, T.C. (2016). the application of the tourist carrying capacity technique and its critical analysis for tourism planning. Tourism Planning \& Development, 13(1), 72-87. https://doi.org/10.1080/21568316.2015.1076512

Guo, W., \& Chung, S. (2017). Remaking tourism carrying capacity frameworks for geoparks. DEStech Transactions on Social Science, Education and Human Science. https://doi.org/10.12783/dtssehs/asshm2016/8357 
Hennessy, E., \& McCleary, A. (2011). Nature's Eden? The production and effects of 'pristine' nature in the Galapagos Islands. Island Studies Journal, 6(2), 131-156.

Hughes, G. (1995). The cultural construction of sustainable tourism. Tourism Management, 16(1), 49-59. https://doi.org/10.1016/0261-5177(94)00007-w

Inskeep, E. (1991). Tourism planning: an integrated and sustainable development approach. Van Nostrand Reinhold.

IPMA (2018). Meteorological dataset. Instituto Português do Mar e da Atmosfera.

IUCN (2014). Laurissilva of Madeira - 2014 conservation outlook assessment. https://www.worldheritageoutlook.iucn.org/node/1097

IUCN (2017). Laurissilva of Madeira - 2017 conservation outlook assessment. https://www.worldheritageoutlook.iucn.org/node/1097

Joshi, S., \& Dahal, R. (2019). Relationship between Social Carrying Capacity and Tourism Carrying Capacity: A case of Annapurna Conservation Area, Nepal. Journal of Tourism and Hospitality Education, 9, 9-29.

Jurado, E.N., Damian, I.M., \& Fernández-Morales, A. (2013). Carrying capacity model applied in coastal destinations. Annals of Tourism Research, 43, 1-19. https://doi.org/10.1016/j.annals.2013.03.005

Jurado, E.N., Tejada, M.T., García, F.A., González, J.C., Macías, R.C., Peña, J. D., Gutiérrez, F.F., Fernández, G.G., Gallego, M.L., García, G.M., Gutiérrez; O.M, \& Concha, F.N.. (2012). Carrying capacity assessment for tourist destinations. Methodology for the creation of synthetic indicators applied in a coastal area. Tourism Management, 33(6), 1337-1346. https://doi.org/10.1016/j.tourman.2011.12.017

Kuchta, D. (2005). Fuzzy solution of the linear programming problem with interval coefficients in the constraints. Badania Operacyjne i Decyzje, 3-4, 35-42.

Kuss, F.R., Graefe, A.R., \& Vaske, J.J. (1990). Visitor impact management: A review of research (Vol. 1). National Parks \& Conservation Association.

López-Bonilla, L.M., \& López-Bonilla, J.M. (2008). La capacidad de carga turística: revisión crítica de un instrumento de medida de sostenibilidad. El Periplo Sustentable, 15, 116-134.

Manning, R. (2011). Studies in outdoor recreation: Search and research for satisfaction. Oregon State University Press.

Manning, R. (2007). Parks and carrying capacity: Commons without tragedy. Island Press.

Manning, R. (2002). How much is too much? Carrying capacity of national parks and protected areas. In A. Arnberger, C. Brandenburg, \& A. Muhar (Eds.), Monitoring and Management of Visitor Flows in Recreational and Protected Areas Conference Proceedings (pp. pages 306-313). Bodenkultur University.

Manning, R. (2001). Visitor experience and resource protection: A framework for managing the carrying capacity of national parks. Journal of Park E Recreation Administration, 19, 93-108.

McKercher, B. (1993). Some fundamental truths about tourism: understanding tourism's social and environmental impacts. Journal of Sustainable Tourism, 1(1), 6-16. https://doi.org/10.1080/09669589309450697

Miller, Z., Fefer, J., Kraja, A., Lash, B., \& Freimund, W. (2017). Perspectives on visitor use management in the national parks. The George Wright Forum, 34(1), 37-44. 
Mirkarimi, S.H., Mohammadzadeh, M., \& Galdavi, S. (2015). Social and recreational carrying capacity assessment of Daland Forest Park, Golestan, Iran. Environmental Resources Research, 3(2), 191-202. doi:10.22069/ijerr.2015.2714

Oliveira, P., \& Pereira, P.T. (2008). Who values what in a tourism destination? the case of Madeira Island. Tourism Economics, 14(1), 155-168. https://doi.org/10.5367/000000008783554758

Prakash, S.L., Perera, P., Newsome, D., Kusuminda, T., \& Walker, O. (2019). Reasons for visitor dissatisfaction with wildlife tourism experiences at highly visited national parks in Sri Lanka. Journal of Outdoor Recreation and Tourism, 25, 102-112. https://doi.org/10.1016/j.jort.2018.07.004

Pröbstl-Haider, U., Dabrowska, K., \& Haider, W. (2016). Risk perception and preferences of mountain tourists in light of glacial retreat and permafrost degradation in the Austrian Alps. Journal of Outdoor Recreation and Tourism, 13, 66-78. https://doi.org/10.1016/j.jort.2016.02.002

Queiroz, R.E., Ventura, M.A., Guerreiro, J.A., \& Cunha, R.T.D. (2014). Carrying capacity of hiking trails in Natura 2000 sites: a case study from North Atlantic Islands (Azores, Portugal). Revista de Gestão Costeira Integrada-Journal of Integrated Coastal Zone Management, 14(2), 233-242. https://doi.org/10.5894/rgci471

Quintal, R., \& Fernandes, M. (2010). Levadas and footpaths of Madeira. Francisco Ribeiro.

Ribeiro, M.F., Ferreira, J.C., \& Silva, C.P. (2011). The sustainable carrying capacity as a tool for environmental beach management. Journal of Coastal Research, SI64, 1411-1414.

Saarinen, J. (2006). Traditions of sustainability in tourism studies. Annals of Tourism Research, 33(4), 1121-1140. https://doi.org/10.1016/j.annals.2006.06.007

Saveriades, A. (2000). Establishing the social tourism carrying capacity for the tourist resorts of the East coast of the Republic of Cyprus. Tourism Management, 21(2), 147-156. https://doi.org/10.1016/s0261-5177(99)00044-8

Shelby, B., \& Heberlein, T.A. (1987). Carrying capacity in recreation settings. Oregon State University Press.

Shelby, B., \& Heberlein, T.A. (1984). A conceptual framework for carrying capacity determination. $\quad$ Leisure $\quad$ Sciences, $\quad 6(4), \quad 433-451$. https://doi.org/10.1080/01490408409513047

Sousa, J.F. (2019). Susana Prada desmonta relatório sobre a Laurissilva que nem a UNESCO conhecia. Diário de Notícias da Madeira. https://www.dnoticias.pt/madeira/susanaprada-desmonta-relatorio-sobre-a-laurissilva-que-nem-a-unesco-conheciaGK4491558\#

Stankey, G.H. (1988). Carrying capacity in recreation settings. Bo Shelby and Tom Heberlein. Journal of Leisure Research, 20(1), 81-83. https://doi.org/10.1080/00222216.1988.11969759

Stankey, G.H., Cole, D.N., Lucas, R.C., Petersen, M.E., \& Frissell, S.S. (1985). The limits of acceptable change (LAC) system for wilderness planning. https://doi.org/10.5962/bhl.title.109310

UNTWO (2018). European Union tourism trends. https://www.eunwto.org/doi/book/10.18111/9789284419470 
UNESCO (2014). Periodic report - Section II: Laurisilva of Madeira. http://whc.unesco.org/en/list/934/documents

UNESCO (2009). Laurisilva of Madeira (Portugal). https://whc.unesco.org/en/decisions/1817 UNESCO (1999). Inscriptions on the World Heritage List: The Laurisilva of Madeira (Portugal). https://whc.unesco.org/uploads/nominations/934.pdf

U.S. National Park Service. (1997). Visitor experience and resource protection process. http://obpanc.org/DOI-AdminRecord/0048953-0049060.pdf

Wagar, J.A. (1964). The carrying capacity of wild lands for recreation. Society of American Foresters. Ye, F., Park, J., Wang, F., \& Hu, X. (2020). Analysis of early warning spatial and temporal differences of tourism carrying capacity in China's island cities. Sustainability, 12(4), 116. https://doi.org/10.3390/su12041328

Zacarias, D.A., Williams, A.T., \& Newton, A. (2011). Recreation carrying capacity estimations to support beach management at Praia de Faro, Portugal. Applied Geography, 31(3), 1075-1081. https://doi.org/10.1016/j.apgeog.2011.01.020

Zehrer, A., \& Raich, F. (2016). The impact of perceived crowding on customer satisfaction. Journal of Hospitality and Tourism Management, 29, 88-98. https://doi.org/10.1016/j.jhtm.2016.06.007 